\title{
Peliosis hepatis and systemic lupus erythematosus: A rare condition identified by magnetic resonance imaging
}

\author{
Eduardo Ferreira Borba ${ }^{4 *}$ \\ ${ }^{1}$ MD. Rheumatology Division, Hospital das Clínicas da Faculdade de Medicina da Universidade de São Paulo (HC-FMUSP), São Paulo, SP, Brazil
${ }^{2}$ MD. Pneumology Division, Hospital das Clínicas da Faculdade de Medicina da Universidade de São Paulo (HC-FMUSP), São Paulo, SP, Brazil
${ }^{3}$ MD. Radiology Division, Hospital das Clínicas da Faculdade de Medicina da Universidade de São Paulo (HC-FMUSP), São Paulo, SP, Brazil
${ }^{4}$ PhD. Rheumatology Division, Hospital das Clínicas da Faculdade de Medicina da Universidade de São Paulo (HC-FMUSP), São Paulo, SP, Brazil
}

Rafael Alves Cordeiro ${ }^{1} \oplus$, Leonardo Santos HofF ${ }^{1}$, Marcos Vinícius Fernandes Garcia ${ }^{2}$, Hilton Muniz Leão Filho ${ }^{3}$,

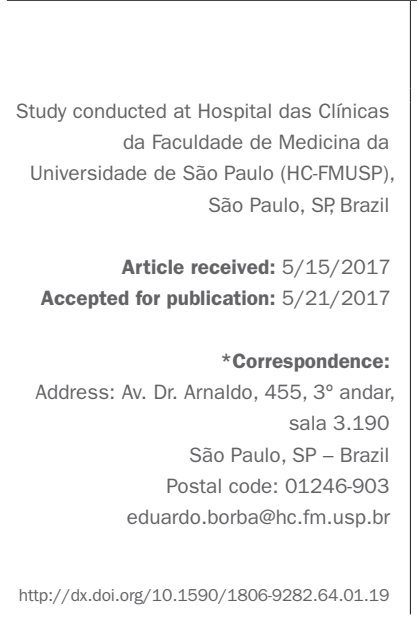

\section{INTRODUCTION}

Peliosis hepatis $(\mathrm{PH})$ is characterized by multiple cavities filled with blood scattered throughout liver parenchyma. ${ }^{1}$ There are many conditions associated with it, including infectious diseases (tuberculosis, acquired immunodeficiency syndrome), immunological disorders (post-transplant immunodeficiency), cancer (hematologic malignancies, hepatocellular carcinoma) and drugs (anabolic steroids, oral contraceptives and immunosuppressive drugs such as glucocorticoids, azathioprine and cyclosporine). ${ }^{2}$ However, etiology is unknown in up to $50 \%$ of cases. ${ }^{3}$

To our knowledge, only three case reports linking PH to systemic lupus erythematosus (SLE) were published so far. ${ }^{4-6}$ Although changes in liver tests are common in patients with SLE, in most cases the liver has a normal morphology ${ }^{4,5}$ In this case, we highlight the role of magnetic resonance imaging in the identification of $\mathrm{PH}$ in a patient with SLE.

\section{Case report}

In 2010, a 59-year-old white female SLE patient presented at our institution with upper abdominal pain for the past 6 months. The pain was mild, intermittent and not related with feeding. She was diagnosed with lupus when she was 19 years old, having symptoms of arthritis, nephritis, transverse myelitis, thrombocytopenia and cutane- ous manifestations. Antinuclear antibodies tested positive $(1 / 1,280$, homogeneous nuclear pattern) as well as anti-dsDNA antibodies. She was exposed to high doses of prednisone, intravenous cyclophosphamide, azathioprine and dapsone. She is currently being treated with prednisone $7.5 \mathrm{mg}$ daily and mycophenolate mofetil $1 \mathrm{~g}$ bid. She denied alcohol abuse, smoking or use of illicit drugs.

At the time of this evaluation, laboratory tests showed: hemoglobin $16.8 \mathrm{mg} / \mathrm{dL}$, leukocytes $14,770 / \mathrm{mm}^{3}$ without immature forms, platelets $73.000 / \mathrm{mm}^{3}$ (reference: 150,000 $450,000 / \mathrm{mm}^{3}$ ), creatinine $1.39 \mathrm{mg} / \mathrm{dL}$ (creatinine clearance $45 \mathrm{~mL} / \mathrm{min}$ ), erythrocyte sedimentation rate $2 \mathrm{~mm} /$ hour, C-reactive protein $<3 \mathrm{mg} / \mathrm{dL}, \mathrm{C} 3$ and $\mathrm{C} 4$ within normal range. Liver function panel revealed aspartate aminotransferase $48 \mathrm{U} / \mathrm{L}$ (reference: $<31 \mathrm{U} / \mathrm{L}$ ), alanine aminotransferase $60 \mathrm{U} / \mathrm{L}$ (reference: < $31 \mathrm{U} / \mathrm{L}$ ), total bilirubin, gamma-glutamyl transferase, alkaline phosphatase, albumin and coagulation within normal limits. She was negative for viral hepatitis and for anti-smooth muscle antibody and anti-LKM.

Abdominal ultrasonography revealed multiple nodules smaller than $1 \mathrm{~cm}$, slightly hyperechoic, with imprecise margins and a diffuse distribution throughout the liver parenchyma, most evident in the left lobe. Magnetic resonance imaging (MRI) of the upper abdomen showed numerous tiny nodes with high signal intensity on $\mathrm{T} 2$ and progressive enhancement by contrast, most evident in the late phase. 
After 3 years of follow-up, a new MRI showed an increase in the number of nodular formations previously identified (Figure 1). During this period, she spontaneously recovered from abdominal pain and the liver function panel remained unchanged.

\section{Discussion}

PH was first described by Schoenlank in 1916 . $^{7}$ Since then, the pathogenesis of $\mathrm{PH}$ remains unclear, although several hypotheses have been proposed. It seems to be related to obstruction of sinusoidal blood flow, direct injury of sinusoidal barrier and focal hepatocellular necrosis. ${ }^{8}$ Peliotic cysts may present with variable morphology and size, ranging from smaller than a millimeter to several centimeters. The mean length of the cavities seems predictive of hepatomegaly and portal hypertension. ${ }^{9}$

It may be asymptomatic and found incidentally only at necropsy. ${ }^{10}$ Matsumoto et al. ${ }^{4}$ did a histopathological evaluation of 52 livers from patients with SLE (51 necropsies and one surgery). In this study, $\mathrm{PH}$ was found in six patients, three of whom had received high doses of glucocorticoids, which could be related to the onset of the lesions.

Langlet et al..$^{5}$ described a severe acute pancreatitis associated with PH in an SLE patient. In this report, pancreatitis and liver involvement were ascribed to widespread vasculitis and the patient was treated with pulse methylprednisolone, followed by azathioprine. Despite the chronic use of these drugs possibly being involved with the development of $\mathrm{PH}$, the authors described the reduction of peliotic lesions after treatment.

MRI of uncomplicated PH may reveal mild lesions with high signal intensity on T2-weighted images due to subacute bleeding. ${ }^{3,9}$ Other possible findings include hepatomegaly, signs of acute liver failure and breakage of larger peliotic lesions resulting in severe intraperitoneal hemorrhage and shock. ${ }^{11,12}$

Despite the appearance of the MRI lesions described in this report being similar to other vascular lesions (e.g. hemangiomas), diffuse distribution and temporal progression strongly suggest $\mathrm{PH}$. An important differential diagnosis is hepatic hemangiomatosis, but that would present with confluent infiltrative lesions, often associated with hepatomegaly. Biliary hamartomas are similar to $\mathrm{PH}$ on T2-weighted images, however, they usually do not exhibit enhancement and do not progress significantly throughout the years. ${ }^{13-15}$

$\mathrm{PH}$ is a rare vascular condition that should encompass the differential diagnosis of atypical liver damage in patients with SLE. Liver biopsy remains the gold standard diagnostic test; nonetheless, given the risk of bleeding, non-invasive diagnostic tools such as MRI are often used to differentiate PH from other unusual hepatic conditions.

\section{Resumo}

Peliose hepática e lúpus eritematoso sistêmico: uma rara condição identificada pela ressonância nuclear magnética

Peliose hepática é uma patologia benigna rara caracterizada pela presença de múltiplas cavidades preenchidas por sangue sem localização preferencial no parênquima do fígado. Pode estar relacionada a uma série de condições etiológicas, dentre elas doenças infecciosas e toxicidade por drogas imunossupressoras. Para nosso conhecimento,

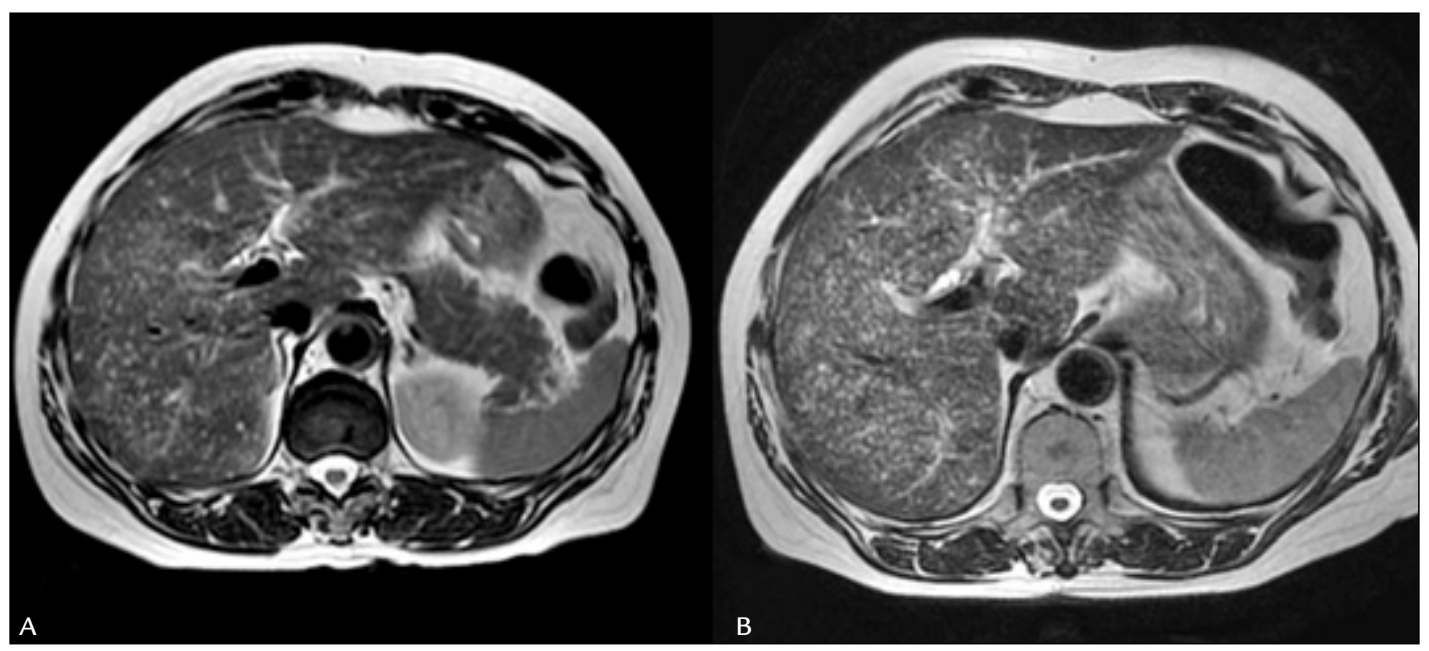

FIGURE 1 Axial T2-weighted MRI: multiple nodular hyperintense lesions that progressed along the three years of follow-up: 2010 (panel A) to 2013 (panel B). 
existem apenas três artigos que abordam a associação entre peliose hepática e lúpus eritematoso sistêmico. Neste relato, descrevemos um caso desta rara condição, destacando a importância da ressonância magnética. Uma breve revisão sobre o tema é apresentada.

\section{Palavras-chave: Peliose Hepática. Imagem por Ressonância} Magnética. Hepatopatias. Lúpus Eritematoso Sistêmico.

\section{References}

1. O'Riordan K, Blei A, Vogelzang R, Nemcek A, Abecassis M. Peliosis hepatis with intrahepatic hemorrhage: successful embolization of the hepatic artery. HPB Surg. 2000; 11(5):353-8.

2. Tsokos M, Erbersdobler A. Pathology of peliosis. Forensic Sci Int. 2005; 149(1):25-33

3. Vignaux O, Legmann P, de Pinieux G, Chaussade S, Spaulding C, Couturier $\mathrm{D}$, et al. Hemorrhagic necrosis due to peliosis hepatis: imaging findings and pathological correlation. Eur Radiol. 1999; 9(3):454-6.

4. Matsumoto T, Yoshimine T, Shimouchi K, Shiotu H, Kuwabara N, Fukuda Y, et al. The liver in systemic lupus erythematosus: pathologic analysis of 52 cases and review of Japanese Autopsy Registry Data. Hum Pathol. 1992; 23(10):1151-8.

5. Langlet P, Karmali R, Deprez C, Brandelet B, Kleynen P, Dratwa M, et al. Severe acute pancreatitis associated with peliosis hepatis in a patient with systemic lupus erythematosus. Acta Gastroenterol Belg. 2001; 64(3):298-300.
6. Okano J, Hoshino U, Shiota G, Murawaki Y, Horie Y, Suou T, et al. [Peliosis hepatis associated with macrothrombocytosis arising in a patient with clinical features of systemic lupus erythematosus and rheumatoid arthritis] Nihon Shokakibyo Gakkai Zasshi. 1995; 92(2):180-3.

7. Schoenlank FW. Ein fall von peliosis hepatis. Virchows Arch Pathol Anat. 1916; 222:358-64.

8. Zafrani ES, Cazier A, Baudelot AM, Feldmann G. Ultrastructural lesions of the liver in human peliosis. A report of 12 cases. Am J Pathol. 1984; 114(3):349-59.

9. Jamadar DA, D'Souza SP, Thomas EA, Giles TE. Case report: radiological appearances in peliosis hepatis. Br J Radiol. 1994; 67(793):102-4

10. Gouya H, Vignaux O, Legmann P, de Pigneux G, Bonnin A. Peliosis hepatis: triphasic helical CT and dynamic MRI findings. Abdom Imaging. 2001; 26(5):507-9.

11. Iannaccone R, Federle MP, Brancatelli G, Matsui O, Fishman EK, Narra VR, et al. Peliosis hepatis: spectrum of imaging findings. AJR Am J Roentgenol. 2006; 187(1):W43-52.

12. Jacquemin E, Pariente D, Fabre M, Huault G, Valayer J, Bernard O. Peliosis hepatis with initial presentation as acute hepatic failure and intraperitoneal hemorrhage in children. J Hepatol. 1999; 30(6):1146-50.

13. Jhaveri KS, Vlachou PA, Guindi M, Fischer S, Khalili K, Cleary SP, et al. Association of hepatic hemangiomatosis with giant cavernous hemangioma in the adult population: prevalence, imaging appearance, and relevance. AJR Am J Roentgenol. 2011; 196(4):809-15

14. Brancatelli G, Federle MP, Vilgrain V, Vullierme MP, Marin D, Lagalla R. Fibropolycystic liver disease: CT and MR imaging findings. Radiographics. 2005; 25(3):659-70

15. Tohmé-Noun C, Cazals D, Noun R, Menassa L, Valla D, Vilgrain V. Multiple biliary hamartomas: magnetic resonance features with histopathologic correlation. Eur Radiol. 2008; 18(3):493-9. 